УДК 355.4.044.7:94"1939/1945"

СЛЮСАРЕНКО А.В.

https://orcid.org/0000-0001-7812-6277

ВєДЄНЕЕВ Д.В.

http://orcid.org/0000-0002-8929-9875

https://doi.org/10.33577/2313-5603.35.2021.206-225

\title{
ТВОРЕННЯ МОДЕЛЕЙ АСИМЕТРИЧНОГО («ГІБРИДНОГО») ПРОТИБОРСТВА ОСНОВНИМИ УЧАСНИКАМИ ДРУГОЇ СВІТОВОЇ ВІЙНИ (1939-1945 РР.)
}

У статті на основі аналізу документальних джерел та спеціальної літератури здійснено виявлення, систематизація та аналіз провідних організаційно-функціональних компонентів систем асиметричного протиборства, створених державами - основними учасниками Другої світової війни (СРСР, Німеччиною, Великою Британією, США) як історичних передумов виникнення воєнно-політичного явища «гібридної війни». Асиметричні дії перетворюються у достатньо самостійну та результативну (аж до стратегічного рівня) форму боротьби. На якісно новий рівень піднялося мистецтво не тільки розвідувальної роботи, але й спеціальних операцій із зміни політичної ситуації, зафронтової розвідувально-диверсійної діяльності. Спеціальні операції почали узгоджуватися зі стратегічними планами ведення бойових кампаній. Спецслужби набули істотного досвіду творення партизансько-підпільного руху як важливого чинника дестабілізації тилів та виснаження противника, створення та управління діяльністю іррегулярних збройних формувань. Набуло розвитку використання із підривною метою етноконфесійного фактора, національно-визвольних та антиколоніальних рухів. Було створено війська спеціального призначення 3 більшістю сучасних організаційно-тактичних рис та бойових можливостей.

Слюсаренко Андрій Віталійович, доктор історичних наук, доцент, заступник начальника академії 3 наукової роботи Національної академії сухопутних військ імені гетьмана Петра Сагайдачного, м. Львів.

Вєдєнєєв Дмитро Валерійович, доктор історичних наук, професор, провідний науковий співробітник Наукового центру Сухопутних військ Національної академії сухопутних військ імені гетьмана Петра Сагайдачного, м. Львів.

(С) Слюсаренко А.В., Вєдєнєєв Д.В., 2021 
Ключові слова: Друга світова війна, асиметричне протиборство, спецслужби, війська спеціального призначення, розвідка, диверсії.

Постановка проблеми. «Стратегія національної безпеки України», затверджена Указом Президента України від 14 вересня 2020 р. № 392, закріпила розширений погляд на комплекс вельми строкатих за походженням й змістовною спрямованістю новітніх загроз державному ладу та суспільству України (Стратегія нащіональної безпеки України... 2020). Наголошується, зокрема, на необхідності серйозного аналізу державою уроків гібридної агресії проти України, регіональних конфліктів та локальних війн для розробки «нових доктринальних підходів до забезпечення воєнної безпеки».

Між тим, генеза явища «гібридної війни» 3 концептуального та функціонального погляду спирається на колосальний історичний досвід непрямого, асиметричного протиборства, його доктринального осмислення, інституалізації та застосування за допомогою сучасних організаційних, інтелектуальних, технологічних можливостей. Якісним історичним етапом на шляху формування концептуальних та організаційно-функціональних засад асиметричного протиборства та передумов до формування сучасних уявлень й практики «гібридної війни» стала саме Друга світова війна 1939-1945 pp.

Аналіз основних досліджень $і$ публікащій. Розгортання «холодної війни», антиколоніальних рухів та специфіка війн повоєнного періоду підштовхували до пошуку нетрадиційних уявлень i розробок щодо стратегічних засад конфліктності, своєрідним маніфестом чого стала книга відомого англійського воєнного теоретика Б. Ліддела-Гарта (1895-1970) «Стратегія непрямих дій» (Лиддел Гарт Б.Х., 1957). Зарубіжні дослідники діяльності спецслужб та спецвійськ (передовсім - британські й американські) зосередилися на аналізі операцій власних та гітлерівських спецслужб, вивчені новітніх методів оперативного мистецтва, механізмів спецпропаганди, використання етноконфесійного та іредентистського чинників (Кукридж Э. (1959); Герэн А., Варэн Ж. (1985); Маккензи У. (2004); Маклахан Д. (1971), розвитку військ спецпризначення (Нейландс Р. (2005); Паркер Дж. (2003) тощо.

Підвищена увага стала приділятися організації та використанню іррегулярних збройних формувань (Диксон Ч.О., Гейльбрунн О., (1957); Ионг Луи де (1956). Дослідження досвіду діяльності розвідувально-диверсійних формувань органів НКВС-НКДБ та 
спецструктур партизанського руху виступало одним із пріоритетних напрямів роботи науковців КДБ СРСР (Андрианов В.Н. (1971); Брайко П.С., Старинов И.Г. (1983); Коровин В.В. (1968). Крім того, серйозну увагу було приділено вивченню розвідувально-підривної діяльності гітлерівських спецслужб (Авдеев Ю.И.(1985); Александров Л.Г. (1972); Барков Л. (1971); Калинкович Н.Н. (1985); Колосов Л.П. (1985); Цветков А.И., Петренко П.Е. (1985).

Відкриття архівних масивів спецслужб та спеціальної наукової літератури дозволило сучасним дослідникам продуктивно продовжити дослідження досвіду «малої війни» й мистецтва асиметричного протиборства 1939 - 1945 рр. (Попов А.Ю. (2003); Романько О. В. (2006); Сергеев Ф. (1991); Тихонов Ю.Н. (2003), серія книг «Спецназ Гитлера» тощо). Автори даної статті у низці праць вдалися до пошуку історичних коренів особливої ролі спеціальних методів протиборства, які становлять основу феномену «гібридної війни» (Вєдєнєєв, 2014, 2015, 2016; Вєдєнєєв, Слюсаренко, 2017; Слюсаренко, 2019).

Мета статmі. Виявлення, систематизація та аналіз провідних організаційно-функціональних компонентів систем асиметричного протиборства, створених державами - основними учасниками Другої світової війни як історичних передумов виникнення воєнно-політичного явища «гібридної війни».

Виклад основного матеріалу дослідження. Радянська модель спеціальних асиметричних дій. Центральними iї елементами стали 4-те Управління НКВС-НКДБ із організації розвідувальнодиверсійної та іншої підривної діяльності в тилу противника та на окупованій території СРСР та Східної Європи. Наказ НКВС СРСР від 25 серпня 1941 р. № 001151 покладав на 4-ті відділи НКВС-УНКВС організацію партизанського руху, керівництво діяльністю диверсійних груп (ГДА $M B C: \phi .45$, on.1, cnp.102, арк.67-69). Безпосередньо у складі 4-го Управління НКВС Української РСР функції відділів визначалися таким чином:

- перший відділ: керівництво оперативними групами в тилу противника, запровадження агентури в розвідувальні й контррозвідувальні органи, адміністративно-політичні установи противника на окупованій території;

- другий відділ: організація диверсійно-терористичної роботи, ведення розслідування по фактах зради агентури 4-го Управління, допит військовополонених, керівництво 4-ми підрозділами обласних УНКДБ; 
- третій відділ: матеріально-технічне забезпечення агентурнооперативної роботи, оперативний облік, інформаційна робота, оперативна техніка та виготовлення документів прикриття (ГДА СБУ: ф. 60, спр. 83529, ч. 1, арк. 18-21).

До основних видів власне зафронтових оперативних формувань НКВС-НКДБ відносилися:

- агентурно-оперативні групи, або ж спецгрупи (3-5 агентів органів держбезпеки, що пройшли певну підготовку для дій у близькому тилу з розвідувальними завданнями);

- оперативно-чекістські, або ж розвідувально-диверсійні групи (5-8 кадрових співробітників держбезпеки, які виводилися за лінію фронту для організації розвідувально-диверсійної роботи 3 позицій, як правило, партизанських загонів);

- оперативно-чекістські групи спеціального призначення (10-15 і більше співробітників НКВС-НКДБ, виведених на територію іноземних держав для виконання спеціальних розвідувальнодиверсійних завдань);

- оперативно-чекістські бази або загони (озброєні загони 3 кадрових співробітників, агентів спецслужби, партизан, чисельністю до 100 і більше осіб, які вели активну диверсійно-терористичну боротьбу на комунікаціях проти важливих об'єктів противника, слугували основою для формування партизанських сил тощо). Загалом НКВС-НКДБ УРСР за роки війни створили 135 таких формувань (7500 учасників).

Серед провідних завдань зафронтових оперативних формувань можна визначити такі:

- y галузі розвідувальної роботи: збір та передача командуванню Червоної Армії інформації про дислокацію, чисельність, озброєння, штаби військ противника, систему постачання, а також про спеціальні, каральні, адміністративні органи окупаційного режиму, формування колаборантів тощо;

- стосовно диверсійної роботи: порушення нормальної роботи прифронтових і тилових комунікацій ворога, виведення 3 ладу військових та промислових об'єктів, запасів стратегічних матеріалів, організація спецпропаганди тощо;

- у галузі контррозвідувальної роботи: виявлення та вивчення форм і методів роботи органів розвідки та контррозвідки агресорів, їх карально-поліцейських структур, запровадження в них власної агентури, розклад зсередини пронімецьких формувань колаборантів, 
контррозвідувальний захист партизанських формувань тощо (Коровин, 1968: 23-24).

У ході війни та залежно від зміни стратегічної та оперативної обстановки, потреб Діючої армії розпорядчими документами корегувалися i завдання 4 Управління НКВС-НКДБ УРСР. Так, перехід Червоної Армії у стратегічний наступ із звільнення України від гітлерівців викликав необхідність активізації диверсійної роботи в тилу противника. Ставилося завдання вербування спеціально підготовлених, рішучих агентів та агентурних груп для їх виведення в тил противника. Наголошувалося на необхідності підбору агентіввербувальників із зв'язками серед персоналу залізниць та промислових підприємств, здатних виводити 3 ладу комунікації, мости, ешелони, склади, бази пально-мастильних матеріалів, військові заводи. У розпалі Битви за Дніпро диверсанти вивели 3 ладу чимало військових об'єктів противника, активно діяли на комунікаціях, полегшуючи наступ фронтів.

Станом на початок вересня 1941 р. 4-й відділ НКВС УРСР вивів до тилу противника 63 партизанські загони (4855 бійців), підготував до зафронтової роботи ще 80 загонів (2409 осіб), 434 загони (12561 осіб) вважалися підготовленими для осідання у разі приходу окупантів. Крім того, підготовку пройшло 285 окремих партизанських та диверсійних груп з 1460 учасниками. До жовтня загалом вдалося вивести в тил противника 122 партизанських загони (5809 бійців) (ГДА СБУ: ф. 60, спр. 83051, ч. 1, арк. 38).

Загалом за роки війни органи держбезпеки СРСР вивели за лінію фронту 2222 оперативні групи (з яких НКВС-НКДБ УРСР сформували 677). Від них було отримано 4418 цінних розвідувальних повідомлень про становище за смугою фронту, з яких 1358 направили до Генштабу Червоної Армії, 420 - командуванню фронтів, 629 - командуванню авіації далекої дії для завдання бомбових ударів.

Загальний внесок у перемогу над гітлеризмом опергруп, спеціальних загонів та інших формувань 4-го Управління НКВСНКДБ УРСР за роки війни був таким: 26 тис. убитих і поранених, 3329 полонених, 6747 роззброєних вояків ворога, 25 знищених генералів і високих чиновників окупаційної адміністрації, 121 співробітник спецслужб Німеччини та іï союзників. Було виведено 3 ладу 15 військових заводів і 23 підприємства, 6 електростанцій, 27 складів, 92 залізничних мости, 41 шосейний міст. Підірвано 
242 ешелони (311 паротяг, до 2500 вагонів), 5 бронепотягів і платформ, знищено 43 літаки, 135 танків, 115 гармат і мінометів противника (ГДА СБУ: ф. 60, сnр. 86751, m. 46, арк. 43-45).

Діяльність зафронтових оперативних груп під час оборони та визволення України, Східної Європи сприяла розвідувальному забезпеченню Діючої армії, розгортанню партизанського руху, підриву військово-економічного потенціалу противника, формуванню агентурної мережі за кордоном. Для вивчення досвіду асиметричного протистояння становить науково-практичний інтерес специфіка діяльності органів безпеки та військової розвідки із творення підрозділів із спеціалізацією на розвідувально-диверсійній роботі за лінією фронту, розгортання партизанського руху та його спеціальних підрозділів (Слюсаренко, Вєдєнєєв, 2017:17-18).

У практику асиметричних дій радянських спецслужб увійшло і формування національних розвідувально-диверсійних частин. 3 1939 - 1940 рр. створюються окремі китайські та корейські загони для дій проти Японії, котра окупувала з 1931 р. Маньчжурію і не приховувала планів захоплення радянського Далекого Сходу й Забайкалля, які увійшли до 88-ї стрілецької бригади Далекосхідного фронту (для виконання розвідувально-диверсійних завдань у тилу противника). Окремі групи бригади застосовувалися для виконання спецзавдань в Кореї та Маньчжурії в інтересах радянського командування до 1945 p. Зокрема, ii вояками була реорганізована підпільна мережа опору в Кореї в 1942 р. (див.: Попов И.М., Лавренев С.Я., Богданов В.Н., 2005).

Нацистський Третій рейх створив оригінальну й потужну систему асиметричної (гібридної) війни, котра значно випередила час та акумулювала багато із тактико-технологічних алгоритмів та прийомів неконвенційного протиборства, стала однією із передумов масштабних успіхів «тотальної війни» - стрижня воєнно-політичної доктрини рейху.

Гітлерівській системі асиметричних дій були властиві такі риси:

- забезпечення максимальної централізації управління розвідкою й підривною діяльністю в широкому розумінні, підпорядкування органів спеціальної діяльності вищому воєнно-політичного проводу рейху;

- настанова на «тотальність» (багатоманітність за спрямуваннями) розвідувальної роботи, іiі тісну координованість 3 
геополітичними, зовнішньополітичними та воєнно-стратегічними концепціями Німеччини;

- курс на перетворення розвідувально-підривних механізмів на важливий інструмент «блискавичної війни»;

- створення «п'ятої колони» на території потенційних противників й насадження агентури в управлінських та ділових колах зарубіжних держав, перехоплення важелів політичного управління;

- інспірування та оперативне використання націоналістичних, сепаратистських, антиколоніальних та інших антиурядових рухів та організацій, а також німецької діаспори;

- масштабне дезінформування противника;

- психологічна війна та розклад духу населення й військ противника;

- застосування розвідувально-диверсійних спецпідрозділів, укомплектованих, у т.ч., представниками народів країн, проти яких здійснюється агресія;

- розвиток технічних видів розвідки, використання досягнень науково-технічного прогресу та інноваційних наукових досліджень (Авдеев, 1985: 114-115; Барков Л., 1971: 8-13; Вєдєнєєв, 2016: 333-334).

Під час реорганізації органів військового управління Німеччини в 1938 р. у структурі військової спецслужби - абверу, запровадили орган асиметричної (комплексної) розвідувально-підривної діяльності - відділ абвер-2. До абвер-2 (А-2) до 1941 р. входили:

група управління;

Група 2-A («Cxid»), на яку покладалося загальне керівництво розвідувально-диверсійною роботою та периферійними органами абвер-2 на Східному фронті. Група поділялася на функціональні реферати:

IOH: створення повстансько-підпільних груп в тилу радянських військ;

$\mathrm{COH:} \mathrm{закидання} \mathrm{диверсійної} \mathrm{агентури} \mathrm{в} \mathrm{глибокий} \mathrm{тил}$ радянських військ, керівництво диверсійною роботою фронтових команд А-2;

AI: організація спецпропаганди, пропагандистської роботи фронтових команд А-2;

АЛ: авіаційна підтримка диверсійних груп, їх парашутнодесантна підготовка. 
Група В: розвідувально-диверсійна та терористична діяльність проти держав Західної Свропи;

Група 3О: розвідувально-диверсійна та терористична діяльність на Балканах, Близькому та Середньому Сході;

Група T: розробка та виготовлення мінно-вибухової техніки, спецзасобів, засобів зв'язку, фотографування, радіопеленгації, тайнопису тощо (Ионг Луи де, 1956: 83-84).

Аншлюс Австрії у березні 1938 р. став багато в чому наслідком спецоперацій абверу. До 1937 р. на ключові пости в силових відомствах, апарату президента, відомствах цієї держави розмістилися німецькі агенти, за допомогою абверу створили загони бойовиків.

Зусиллями абвер-2 була забезпечена «п'ята колона» для анексії населеної 3 млн. етнічних німців Судетської області Чехословаччини. У травні 1938 р. розробили план «Грюн» 3 окупації країни, хоча вже 31935 р. Берлін фінансував і підтримував місцевих сепаратистів на чолі 3 Гейнлейном. В навчальних таборах у Бранденбурзі створювалися бойові та диверсійні групи судетських німців.

У березні 1940 р. агентура абвера-2, місцеві диверсанти 3 числа членів нацистських організацій та сепаратистів сприяли окупації Данії та Норвегії (дії агентури, зокрема, викликали перешкоди військового управління, сприяли захопленню десантами Осло і стратегічного порту Нарвік тощо).

На Східному фронті з 1941 р. по лінії абвер-2 створили шість «диверсійних абверкоманд (№№201-206), кожна 3 них мала по 2-6 абвергрупи, спецшколи. Спецшколи абвера на Східному фронті одночасно готували 4175 - 5765 розвідників й диверсантів та 4200 - 4700 пропагандистів. Лише в 1942 р. було підготовлено 2,5 тис. диверсантів, а кількість закинутих за лінію фронту (у порівнянні 31939 р.) зросла в 21 раз (ГДА СБУ: ф. 13, д. 693, арк. 49-50; Александров Л.Г. (1972):202; Сергеев Ф. (1991): 43).

Абвер енергійно працював з начіональними, антиколоніальним, сепаратистськими рухами. Так, у співробітництві з організацією «Вільна Індія», Японією та Італією створили 40-тисячну Індійську національну армію, Тимчасовий «уряд вільної Індії» оголосив війну Великобританії, готувалися диверсійні кадри з числа індусів. 3 грудня 1941 р. абвер-2 розгорнув підготовку диверсійних груп й повстанських загонів пуштунських племен на кордонах 
Британської Індії. План «Аманулла», розроблений спецслужбами Німеччини, передбачав повстання пуштунських племен в Афганістані, Белуджистані з подальшою окупацією Афганістану. Готувалася 40-тисячна армія 3 емігрантів для вторгнення в радянську Середню Азію. Планувалося створити маріонетковий «Великий Туркестан». Спецслужбам СРСР та Британії вдалося попередити державний переворот і перехід під контроль Берліна Ірану, де працювало 6,5 тис. німецьких «спеціалістів», було перекинуто 11 тис. тонн зброї та боєприпасів. Готувалася диверсійна кампанія проти нафтовидобувного басейну Баку (Советские органы государственной безопасности в Великой Отечественной войне... (1985): III, 75; Калинкович Н.Н. (1985): 99-105; Тихонов Ю.Н. (2003).

Окремо доцільно згадати про створення в системі РСХА спеціального розвідувально-диверсійного органу «Підприємство Цепелін» (весна 1942 р.). До його функцій відносилося проведення масштабної, довгострокової диверсійної та розкладницької роботи в радянському тилу на основі інспірування націоналістичних, етносепаратистських настроїв, 3 використанням відповідних «національних формувань» із представників різних народів СРСР (Советские органь государственной безопасности в Великой Отечественной войне (1985): III, 916).

Гітлерівці виступали піонерами щодо створення військ спечпризначення, бойових розвідувально-диверсійних підрозділів, у т.ч. сформованих за етнічною ознакою для дій у середовищі відповідних народів і регіонів. Найбільш відомим спецпідрозділом став підпорядкований абверу-2 батальйон (з весни 1940 р.) «навчальний полк» «Бранденбург-800», у квітні 1942 р. перетворений у дивізію. «Бранденбург-800» (по суті, перша частина військ спецпризначення у сучасному розумінні) визначався для диверсій та терору в тилу противника, захоплення важливих об'єктів, підготовки кадрів диверсантів й розгортання повстанських рухів. За час існував він підготував десятки тисяч диверсантів та бойовиків, у т.ч. для дій в Індії, Ірані, на Арабському Сході, в Англії і США. Його спецгрупи сприяли бліцкригу в перші дні нападу Німеччини на СРСР у червні 1941 р., виводячи з ладу лінії зв' язку, захоплюючи неушкодженими мости, знищуючи командний склад. 
Полк «Бранденбург-800» складався із штабної роти (групи англійська, російська, африканська, арабська, румунська та інші), роти зв' язку, навчального батальйону, п'яти бойових батальйонів 4-ротного складу. Дивізія «Бранденбург-800» включала полки за № 801-805 3-батальойнного складу, навчальний полк, роту пропаганди, роту морської піхоти. Навесні 1943 р. на основі 805-го полку створили навчальний полк «Курфюрст» для підготовки диверсантів та агентури для дій в зарубіжних державах.

Серед спецпідрозділів абвер-2, створених із представників народів СРСР для дій в тилу Червоної Армії відомі, зокрема:

диверсійні підрозділи «Роланд» і «Нахтигаль» (українські), застосовувалися на початку війни у Західній Україні;

диверсійні підрозділи «Межа каті» (латиський) та «Ерна» (естонський);

розвідувально-диверсійні групи «Тамара-I» i «Тамара-II», створені влітку 1941 р. за допомогою «Грузинського військового комітету», які діяли в радянському тилу на Кавказі;

«Горець» («Бергман»), диверсійний батальйон полку «Бранденбург-800», сформований у листопаді 1941 р. (до 1500 бійців). Він мав групи спецпризначення, кавалерійські ескадрони, дві «грузинські» роти, роти, укомплектовані карачаївцями, кабардинцями, осетинами, інгушами, чеченцями, азербайджанцями, вірменами. Вів активні диверсійні дії на Північному Кавказі, брав участь в антипартизанських операціях в Криму, Греції, на Балканах.

«Шамиль», спецпідрозділ 804-го полку дивізії «Бранденбург800», сформований у жовтні 1941 р. 3 чеченців, дагестанців та інших народів Північного Кавказу, брав участь у численних диверсійних операціях на Північному Кавказі (ГДА СБУ: $p .13$, спр. 693, арк. 13; Цветков А.И., Петренко П.Е. (1985): 67; Колосов Л.П. (1985): 88-89).

Надзвичайно розвинутим став інформаційний компонент машини асиметричної війни Третього рейху, який, зокрема, використовувався і для стратегічної дезінформації противників. Так, наприкінці 1940 р. особисто А. Гітлер поставив завдання із профільної підготовки до війни з СРСР керівникам основних інформаційних центрів - Міністерства пропаганди, МЗС, Головного управління імперської безпеки (РСХА), Східного відділу зовнішньополітичного управління Націонал-соціалістичної партії Німеччини. 
У річищі проблематики нашого дослідження найбільший інтерес становить створення та діяльність британського Управління стратегічних операџій (УСО, 1940-1946рр.), котре стало комплексним інститутом асиметричних дій, сполучаючи розвідувальний пошук із диверсіями стратегічного й оперативно-тактичного рівнів та іншими видами підривних акцій. Велика Британія пішла власним оригінальним шляхом формування системи асиметричних дій з урахуванням вимог воєнного часу й загрози вторгнення німецької армії на Британські острови при перевазі гітлерівських сухопутних сил.

19 липня 1940 р. прем'єр-міністр У. Черчилль подав Воєнному кабінету меморандум про створення Управління спеціальних операцій 3 метою «координації всіх акцій з підривної діяльності і шпигунства на території противника». Основними підрозділами управління виступали три департаменти - пропагандистський (згодом перетворений в Управління політичної війни), операційний та дослідницький; існували регіональні відділи, окремі штабквартири у певних місцевостях («Штаб спецоперацій Середземномор'я», «Індійська місія», «Сінгапурська місія», Загін 133 в Італії тощо). Крім того, УСО відповідало за підготовку до партизанського руху в самій Англії на випадок вторгнення нацистів.

У м. Рангуні відкрили спецшколу, де майбутні спецпризначенці оволодівали диверсійною та агентурно-вербувальною роботою, радіосправою, прийомами самооборони та стрілецькою підготовкою, країнознавством, вивчали техніку поведінки на допитах тощо.

Спецпідрозділ взаємодіяв із іншими розвідслужбами, МЗС та створеним 27 липня 1939 р. Міністерством економічної війни. Інноваційним стало і матеріально-технічне забезпечення УСО. Нічні літаки «Лісандер» могли доставляти диверсантів на окуповану територію, постачати їм зброю та диверсійну техніку (УСО мало власні 138 та 161-шу авіаескадрильї спецпризначення, які лише за 5 міс. 1944 року закинули антифашистським силам в Свропі 45 тис. автоматів і велику кількість боєприпасів). На озброєння диверсантів надходили новинки мінно-вибухової техніки, удосконалені парашути, портативна стрілецька зброя, складальні мотоцикли, міні підводні човни тощо. Існувала лабораторія для підготовки документів прикриття. Загалом через Управління пройшло до 13 тис. співробітників, які взаємодіями із приблизно 1 млн. учасників антигітлерівського та антияпонського опору (Операщии военной разведки (1997): 215-216). 
Серед успішних акцій диверсантів УСО - знищення заводу із виробництва важкої води у норвезькому Веморку, що надовго загальмувало просування гітлерівського атомного проєкту; підрив моста через р. Горгопотамос у Греції, що на кілька місяців порушило постачання німецьких військ у Північній Африці через порти Афін та Пірея (1942р.). Особливо енергійно УСО діяло у Франції, де відбувалися сотні диверсій на заводах та залізницях. Після початку операції «Оверлорд» із висадки союзників у Нормандії, лише за серпень 1944 р. було знищено 688 локомотивів і проведено 2900 диверсій на залізницях.

Однією із передумов успішних непрямих дій британської розвідки стало залучення до неї осіб, розумово й психологічно пристосованих до нестандартних місій, не обтяжених бюрократичними путами та стереотипами мислення військової або державної служби (Маклахан Д. (1971): 120-125).

322 червня 1940 р., за підтримки прем'єр-міністра, спішно почали створюватися батальйони «командос». Особовий склад 2-го батальйону пройшов парашутну підготовку, і підрозділ перейменували в 11-й батальйон спеціальної авіаційної служби (САС; щоб відокремити частини «командос», десантованих повітряним шляхом, від частин спецслужби, які діяли 3 моря). Відчайдушна операція німецьких десантників із захоплення острова Крит підштовхнула розвиток повітрянодесантних частин, на основі 11-го батальйону розгорнули 1-шу парашутну бригаду. Другу парашутну бригаду сформовано в Індії 3 індійських і гуркхських батальйонів. У грудні 1940 р. відкрили навчальний центр на Близькому Сході, у 1942 р. - у горах Шотландії. Це створило передумови для формування власне підрозділів спецпризначення у сучасному розумінні цього слова.

Першим командиром спеціального підрозділу САС вважається лейтенант шотландської гвардії Девід Стерлінг, який у червні 1940 р. вступив добровольцем у 8-й батальйон командос. У липні 1941 р. Д. Стерлінг направив до штабу командування збройними силами на Близькому Сході письмовий план своєї «Концепції застосування малих груп у тилу противника». Новий підрозділ сформували 24 серпня 1941 р. як підрозділ командос та укомплектували винятково $з$ добровольців 8-го батальйону. Під час бойових дій у Північній Африці бійці САС проводили результативні рейди і розвідувально-диверсійні операції проти німецьких військ. 
У вересні 1942 р. виник 1-й полк САС, який організаційно складався з чотирьох британських, одного французького та одного грецького ескадронів, а також відділення човнової служби та нараховував близько 390 бійців. Було здійснено чимало бойових атак на німецькі аеродроми - підрозділи САС знищили майже 400 ворожих літаків, більше, ніж усі Королівські повітряні сили на цьому ТВД.

У 1944 р. полк розширили до бригади у складі чотирьох полків і двох батальйонів (два британських $(1,2-и ̆$ САС) і два французьких полки (3, 4-й САС), бельгійський батальйон (пізніше 5-й полк CAC) і батальйон зв'язку). Основними завданнями бригади були: добування розвідувальних даних про важливі економічні й військові об'єкти; їх знищення або виведення з ладу; проведення психологічних операцій з метою деморалізації особового складу і населення противника; організація саботажу; здійснення терористичних i диверсійних актів у глибокому тилу противника; утворення та підготовка повстанських формувань; участь у антипартизанських операціях тощо (огляд дано за: Кукридж Э. (1959); Маккензи У. (2004); Паркер Дю. (2003); Слюсаренко (2019): 46-58).

Друга світова війна прискорила формування системи асиметричної війни у США. Виходячи із вимог воєнного часу та перших поразок США на Тихому океані від японців, президент США Ф. Рузвельт, долаючи міжвідомчі суперечності та опір угруповань у правлячих колах, вдався до реорганізації національної розвідувальної системи. Управління стратегічних служб (УСС, англ. - OSS) виникло за наказом президента США Ф. Рузвельта від 13 липня 1942 p. (функціонувало до 20 вересня 1945 р., із січня 1946 р. його функції перейшли до Центральної розвідувальної групи як основи формування Центрального розвідувального управління США).

На УСС поклали широке коло функцій гібридної війни та непрямих дій: агентурна розвідка за кордоном, диверсійна робота і саботаж, підтримка Руху опору в Свропі та антияпонських сил у Китаї та Індокитаї, підготовка партизанських сил із числа союзних народів, спецпропаганда і аналітична робота, дослідження із стратегічно важливих питань тощо. Було створено «географічні» розвідувальні резидентури, котрі не лише збирали інформацію, але й вдавалися до активних заходів із зміни політичної ситуації в інтересах США - зокрема, шеф Європейської резидентури в Берні А. Даллес (майбутній директор ЦРУ) сприяв поваленню пронацистського режиму Віши у Франції (операція «Смолоскип»). 
Особливу роль виконував відділ спеціальних операцій. Готувалися диверсійні мобільні групи «Джетс», одна 3 яких провела операцію «Норд» із підриву військового заводу у Норвегії, готувала замах на німецького фізика-ядерника Гейзенберга у нейтральній Швейцарії. Асиметричним кроком УСС стало залучення до співробітництва ватажків італійської мафії для сприяння висадці десанту в Сицилії в 1943 р.

Серед провідних підрозділів УСС - служба з диверсійної роботи на промислових підприємствах окупованої Європи, служба спеціальної пропаганди (залучала профільних спеціалістів Голівуда та рекламного бізнесу), служба дослідницької та аналітичної роботи, служба науково-технічного забезпечення (розробка спеціальної техніки та озброєння). До кінця війни чисельність апарату УСС зросла до 30 тис. співробітників, половина 3 яких були аналітиками, науковцями, носіями нестандартних знань, людьми «вільних професій» (Аленов А., Андреев В. (1965): 45-49; Герэн А., Варэн Ж. (1985): 38-43).

Розпочинається формування і військ спеціального призначення армії США, котрі згодом стали основою перших у світі Сил спеціальних операцій. У 1942 р. офіцер з питань взаємодії 3 Британським генштабом, генерал-майор сухопутних сил США Л. Траскот подав пропозицію генералу Дж. Маршаллу про заснування американського спецпідрозділу «за аналогією з британськими командос», що стало початком формування частин рейнджерів сухопутних сил США. 1 червня 1942 р., за вказівкою начальника штаба армії США генерала Маршалла, починається формування спецпідрозділу «Американські командо», яким надали назву «рейнджери» на честь їх відомих попередників часів Війни за незалежність США 1775-1783 рр. До кінця червня 1942 р. укомплектований добровольцями 1-й батальйон рейнджерів.

Рейнджерів передбачалося використовувати для морських i повітряних десантів, розвідки і диверсій у тилу противника. У 1943 р. ïx застосували в операції «Хаскі» із захоплення о. Сицилія. Однак відсутність відпрацьованої тактики взаємодії рейнджерів із піхотою та іншими сухопутними військами закінчилася для спецназу драматично. У січні 1944 р. під час десантної операції поблизу італійського порту Анці, 1, 3 та 4-й батальйони «рейнджерів Дербі» потрапили в оточення німецької піхоти й танків, не отримали належної підтримки і були майже повністю знищені (з 767 бійців 
уціліло шість). Щоправда, 2-й батальйон рейнджерів відзначився в операції «Оверлорд» (висадка в Нормандіï) 6 червня 1944 р.

Формування американських спецпідрозділів поступово набуло цілеспрямованого характеру, що багато в чому пояснювалося необхідністю протиставити японцям, майстрам війни у специфічних умовах джунглів, спеціально підготовлених вояків. Із листопада 1943 р. у центральній Індії під керівництвом англійських командос «Чіндит» проходили підготовку 3000 вояків США, («загін 5307»). Воюючи у джунглях Бірми проти японців, ці командос отримали прізвисько «мародерів Мерілла» (за ім'ям бригадного генерала Френка Мерілла). На Філіппінах проти японців результативно діяв 6-й батальйон рейнджерів (загалом їх було створено шість по 800 бійців за штатом у кожному) та спецзагін «скаути Аламо» (огляд дано за: Нейландс Р. (2005); Слюсаренко А. (2019):61-65).

Висновки. Якісним кроком на шляху утворення основних інституційних та функціональних компонентів механізму асиметричного протиборства (основи стратегії та інструментарію «гібридної війни») стала Друга світова війна, котра породила певні інституйовані національні моделі асиметричної боротьби. Спеціальні асиметричні дії поступово із способу забезпечення успіху бойових дій перетворюються у достатньо самостійну та результативну (аж до стратегічного рівня) форму боротьби.

Друга світова війна піднесла на якісно новий рівень мистецтво не тільки власне розвідувальної роботи, але й спеціальних операцій із зміни політичної ситуації, зафронтової розвідувально-диверсійної діяльності спецслужб, яка (поряд із партизансько-підпільною боротьбою) перетворилася на дієвий чинник оперативно-стратегічного і стратегічного характеру. Спеціальні операції почали узгоджуватися зі стратегічними планами ведення бойових кампаній.

Спецслужби набули істотного досвіду творення партизанськопідпільного руху як важливого чинника дестабілізації тилів та виснаження противника, створення та управління діяльністю іррегулярних збройних формувань (у т.ч. за етнічною ознакою), що міцно увійшло до арсеналу асиметричної діяльності аж до сучасності.

Набуло результативного розвитку використання із підривною метою партійно-політичного, регіонального, етнічного факторів, національно-визвольних та антиколоніальних рухів, формування на цій основі підконтрольних спеціальним органам етнополітичних, 
сепаратистських, іредентистських та інших керованих структур в інтересах непрямих дій у рамках загальної стратегії підриву військово-політичної стабільності у стані противника. Масового й цілеспрямованого характеру досягає радіо- і друкована пропаганда 3 метою розкладу духу військ і населення противника, яка починає спиратися на спеціалізовані структури, доробки соціальної психології та інших галузей науки.

В цей історичний час було створено війська спеціального призначення з більшістю тих основних організаційно-тактичних рис та бойових можливостей, які вони зберігли і донині. Відбувалося цілеспрямоване створення структур (підрозділів, частин) спеціального призначення, які виокремилися від високомобільних військ (повітрянодесантних військ, морської піхоти, польової розвідки тощо). Оформились прототипи «класичних» військ спеціального призначення (розвідувально-диверсійних за функціями і формами застосування).

Серед них - особлива система підпорядкування та повна або часткова організаційна автономія від збройних сил (армійського командування), високий ступінь та універсалізм бойової та спеціальної підготовки, зосередженість на розвідувально-диверсійній та іншій спеціальній діяльності, підвищена мобільність, тісна взаємодія зі спецслужбами, здатність проводити спеціальні операції, котрі справляли суттєвий вплив на оперативно-тактичну або стратегічну ситуацію тощо.

\section{Використані посилання}

Авдеев Ю.И. (1985). Формирование стратегических установок в области подрывной деятельности фашистской Германии против СССР и их содержание // Труды Высшей Краснознаменной школы КГБ СССР. № 35. С. 113-117.

Александров Л.Г. (1972). Руководящие органы фашистской военной разведки на советско-германском фронте // Труды Высшей Краснознаменной школь КГБ СССР. № 4. С. 202-210.

Аленов А., Андреев В. (1965). Конщерн шпионажа и диверсий. М.: Молодая гвардия. $336 \mathrm{c}$.

Андрианов В.Н. (1971) Борьба советских партизан в годы Великой Отечественной войны. М.: ВКШ КГБ при СМ. СССР. 167 с.

Барков Л. (1971). В дебрях абвера. Таллин: Ээсти Раамат. 238 с.

Брайко П.С., Старинов И.Г. (1983). Партизанская война. М.: В/ч 33965. Ч. $1.335 \mathrm{c}$.

Вєдєнєєв Д. (2014). Розвідувально-диверсійна та контррозвідувальна діяльність органів державної безпеки за лінією фронту в 1941-1945 pp. (за документами НКВС-НКДБ Української РСР) // 3 архівів ВУЧК-ГПГУ-НКВД-КГБ. № 2. С. 291-352. 
Вєдєнєєв Д.В. (2015). Роль спеціальних служб в організації та оперативному забезпеченні розвідувальної роботи партизанського руху на окупованій території України (1941-1944рр.) // Воєнно-історичний вісник. Вип. 2. С. 96-103.

Вєдєнєєв Д.В. Система асиметричного протиборства спецслужб гітлерівської Німеччини // Перспективи розвитку озброєння та військової техніки Сухопутних військ. 3б. тез доповідей Міжнародної науково-технічної конферениії (Львів, 18-20 травня 2016 р.). Львів: НА СВУ, 2016. С. 333-334.

Галузевий державний архів (ГДА) СБ України.

ГДА МВС України.

Герэн А., Варэн Ж. (1985). Люди из ЦРУ. М.: Междунар. отношения. 288 с.

Диксон Ч.О., Гейльбрунн О. (1957). Коммунистические партизанские действия. М.: Издательство иностранной литературы. 291 с.

Ионг Луи де (1958). Пятая колонна в Западной Европе. М.: Иностранная литература. 384 с.

Калинкович Н.Н. (1985). Борьба с подрывной деятельностью противника, осуществляемой под прикрытием панисламизма, пантюркизма в годы Великой Отечественной войны 1941 - 1945 гг. против Туркменистана // Труды ВКШ КГБ СССР. № 36. С. 99 - 105.

Колосов Л.П. (1985). Диверсионно-разведывательные формирования фашистской Германии и некоторые вопросы войсковой борьбы с ними в годы Великой Отечественной войны // Труды ВКШ КГБ СССР. № 35. С.88-95.

Коровин В.В. (1968). Деятельность оперативных групп органов государственной безопасности в тылу противника в годы Великой Отечественной войны. М.: ВШ КГБ. 84 с.

Кукридж Э. (1959). Тайны английской секретной службы. М.: Военное издательство МО СССР. 306 с.

Лиддел Гарт Б.Х. (1957). Стратегия непрямых действий. М.: Иностран. литература. 536 с.

Маккензи У. (2004). Секретная история УСО: Управление специиальных операций в 1940 - 1945 ге. М.: АСТ. 957 с.

Маклахан Д. (1971). Тайны английской разведки. М.: Воениздат. 384 с.

Нейландс Р. (2005). В зоне боевых действий. История войск специиального назначения с 1945 года. М.: ФАИР-ПРЕСС. 378 с.

Операции военной разведки (1997). Минск: Литература. 640 с.

Паркер Дж. (2003). Британские коммандос. М.: Изографус; ЭКСМО. 224 с.

Попов А.Ю. (2003). НКВД и партизанское движение. М.: ОЛМА-ПРЕСС. 383 с.

Попов И.М., Лавренев С.Я., Богданов В.Н. (2005). Корея в огне войны. М.: Кучково поле. 472 с.

Романько О. В. (2006). Советский легион Гитлера. Граждане СССР в рядах вермахта и СС. М.: Издатель Быстров. 640 с.

Сергеев Ф. (1991). Тайные операции нацистской разведки. 1933-1945. М.: Политиздат. 312 с.

Слюсаренко А.В. (2019). Світовий досвід розбудови та застосування сухопутного компоненту Сил спеціальних операцій (друга половина XX початок XXI cm.). Львів: НА СВУ, 2019. С. 46-75. 
Слюсаренко А.В., Вєдєнєєв Д.В. (2017). Спеціальний орган $з$ координації розвідувально-диверсійної діяльності на окупованій гітлерівськими агресорами території України: історичний досвід // Військово-науковий вісник. № 27. С. 3-18.

Стратегія національної безпеки України. Затверджена Указом Президента України від 14 вересня 2020 р. № 392. URL: https://www.rnbo.gov.ua/ua/Ukazy/ 4693.html

Тихонов Ю.Н. (2003). Афганская война Третьего рейха. М.: Олма-Пресс. 383 с.

Цветков А.И., Петренко П.Е. (1985). Борьба советской контрразведки с диверсионно-разведывательными и бандитскими формированиями в годы Великой Отечественной войны // Труды Высшей Краснознаменной школь КГБ СССР. № 34. С. 67-76.

\section{References}

Avdeev Yu.I. (1985). Formation of strategic attitudes in the field of subversive activities of Nazi Germany against the USSR and their content // Proceedings of the Higher School of the Red Banner of the KGB of the USSR. No. 35. P.113-117. (rus.).

Alexandrov L.G. (1972). The governing bodies of the fascist military intelligence on the Soviet-German front // Proceedings of the Higher Red Banner School of the $K G B$ of the USSR. No. 4. P.202-210. (rus.).

Alenov A., Andreev V. (1965). Concern of spionage and sabotage. Moscow: Young Guard. 336 p. (rus.).

Andrianov V.N. (1971)/ The Struggle of Soviet Partisans during the Great Patriotic War. M .: VKSH KGB at SM. USSR. 167 p. (rus.).

Barkov L. (1971). In the wilds of the Abwehr. Tallinn: Eesti Raamat. 238 p. (rus.).

Braiko P.S., Starinov I.G. (1983). Guerrilla warfare. Moscow: Military unit 33965.H.1.335 p. (rus.).

Vedeneyev D. (2014). Development sabotage and counter-intelligence activities of state security agencies behind the line front in 1941-1945. (for the documents of the NKVS-NKDB of the Ukrainian RSR) // Archives of the VUCHK-GPU-NKVD-KGB. No. 2. P.291-352. (ukr.).

Vedeneyev D.V. (2015). The role of special services in the organization and operational safety of development robots and partisan forces on the recoupment of the territory of Ukraine (1941-1944) // Military-Historical Visnik. Vip. 2. Pp. 96-103. (ukr.).

Vedeneyev D.V. The system of asymmetric countermeasures of the special services of the Hitlerite Nimechchin // Prospects for the development of the defense and modern technology of the land military. Zb. abstracts of additional reports of the International Science and Technology Conference (Lviv, 18-20 May 2016). Lviv: NA SVU, 2016. pp. 333-334. (ukr.).

Galuzeviy sovereign archiv (GDA) of the Security Council of Ukraine. (ukr.).

GDA MVS of Ukraine. (ukr.).

Guerin A., Varen J. (1985). People from the CIA. M .: Mezhdunar. relations. 288 p. (rus.).

Dixon C.O., Heilbrunn O. (1957). Communist partisan actions. Moscow: Foreign Literature Publishing House. 291 p. (rus.).

Yong Louis de (1958). Fifth Column in Western Europe. M .: Foreign literature. 384 p. (rus.). 
Kalinkovich N.N. (1985). The fight against subversive activities of the enemy carried out under the cover of pan-Islamism, pan-Turkism during the Great Patriotic War of 1941-1945. against Turkmenistan // Proceedings of the General Staff of the $K G B$ of the USSR. No. 36. P. 99 - 105. (rus.).

Kolosov L.P. (1985). Subversive and reconnaissance formations of Nazi Germany and some issues of military struggle against them during the Great Patriotic War // Proceedings of the VKSH KGB of the USSR. No. 35. P.88-95. (rus.).

Korovin V. V. (1968). The activities of operational groups of state security agencies behind enemy lines during the Great Patriotic War. M .: VSh KGB. 84 p. (rus.).

Cookeridge E. (1959). Secrets of the English Secret Service. M.: Military publishing house of the USSR Ministry of Defense. 306 p. (rus.).

Mackenzie W. (2004). The Secret History of the USO: Special Operations Directorate 1940-1945 M .: AST. 957 p. (rus.).

McLahan D. (1971). Secrets of British intelligence. Moscow: Military Publishing. 384 p. (rus.).

Neilands R. (2005). In a war zone. History of Special Forces since 1945. M.: FAIR-PRESS. 378 p. (rus.).

Military Intelligence Operations (1997). Minsk: Literature. 640 p. (rus.).

Parker J. (2003). British commandos. M .: Isographus; EKSMO. 224 p. (rus.).

Popov A.Yu. (2003). The NKVD and the partisan movement. M .: OLMAPRESS. 383 p. (rus.).

Popov I.M., Lavrenev S.Ya., Bogdanov V.N. (2005). Korea in the flames of war. M .: Kuchkovo field. 472 p. (rus.).

Romanko O.V. (2006). Hitler's Soviet Legion. Citizens of the USSR in the ranks of the Wehrmacht and the SS. M .: Publisher Bystrov. 640 p. (rus.).

Sergeev F. (1991). Covert operations of Nazi intelligence. 1933-1945. M.: Politizdat. 312 p.

(rus.).

Slyusarenko A.V. (2019). World experience of development and deployment land component of the Special Operations Forces (the other half of the XX - the ear of the XXI century). Lviv: NA SVU, 2019, pp. 46-75. (ukr.).

Slyusarenko A.V., Veden€€v D.V. (2017). A special body for the coordination of developmental and sabotage activities for the recoupment of Hitler's aggressors in the territory of Ukraine: historical information // News of Science. No. 27. P. 3-18. (ukr.).

Strategy of the National Security of Ukraine. Approved by the Decree of the President of Ukraine from the 14 th of Sunday, 2020. No. 392. URL: https://www.rnbo.gov.ua/ua/Ukazy/4693.html (ukr.).

Tikhonov Yu.N. (2003). Afghan War of the Third Reich. M .: Olma-Press. 383 p. (rus.).

Tsvetkov A.I., Petrenko P.E. (1985). The struggle of Soviet counterintelligence against sabotage and reconnaissance and bandit formations during the Great Patriotic War // Proceedings of the Higher Red Banner School of the KGB of the USSR. No. 34. P. 67-76. (rus.). 


\section{Sliusarenko A., Viedienieiev D. \\ CREATING THE CONFRONTATION ASYMMETRIC "HYBRID" MODELS BY THE MAIN PARTICIPANTS OF THE SECOND WORLD WAR (1939-1945)}

The article presents systematization and analysis of the main organisationalfunctional components of the asymmetric confrontation systems created by the states - main participants of the Second World War as the historical preconditions to the emergence of military-political "hybrid war" phenomenon. It is constated, that the Second World War became a qualitative historical stage on the way of forming the conceptual and organisational-functional basics of the asymmetric confrontation and preconditions to the forming of the modern "hybrid war" conception and practice.

Asymmetric actions from the way of ensuring of hostilities success gradually became quite independent and effective (till the strategical stage) form of struggle. The Second World War brought to a qualitatively new level of art not only the very intelligence work but also special operation on behalf of political situation changes, intelligent-sabotage activities over the frontline. Special operations became been approved with the strategical plans of the fighting companies conducting.

Special services got the historical experience of the partisan-underground movement as an important factor to the rear destabilisation and exhaustion of the enemy, to create and to manage the activity of irregular armed formations (including be the ethnic signs), which firmly entered the arsenal of the asymmetric activity till the nowadays. Using the party-political, regional and ethnical factors, national-liberation and anticolonial movements by the subversive aim got its effective development.

There were created the special forces, which had the main organisational-tactic features and combat capabilities, that they have saved till nowadays. The purposeful formation of the special forces, which have seceded from the highly mobile troops (airborne troops, marines, field reconnaissance and others) have occurred.

Keywords: Second World War, asymmetric confrontation, special services, special forces, intelligence, sabotage. 